\title{
Development of Monoclonal Antibodies against Human Gastrointestinal Cancer
}

\author{
Yoshiaki Kano, Kazuaki Nakura, Takashi Nakane, \\ Yasuo Ueda, Yahiro Uemura, Kazumasa Yokoyama, \\ Hidehumi Ishida, ${ }^{*}$ Harumasa Ohyanagi* and Youichi \\ SAITOH* \\ Central Research Laboratories, the Green Cross Corporation, \\ Hirakata 573, and *the First Department of Surgery, Kobe \\ University School of Medicine, Kobe 650
}

\begin{abstract}
Kano, Y., Nakura, K., Nakane, T., Ueda, Y., Uemura, Y., Yokoyama, K., Ishida, H., Оhyanagi, H. and Saito , Y. Development of Monoclonal Antibodies against Human Gastrointestinal Cancer. Tohoku J. Exp. Med., 1990, 160 (4), 361373 - We have evaluated approximately 10,000 monoclonal antibodies resulting from 14 hybridization of spleen cells from mice immunized with established cancer cell lines. They were screened by binding assays using cancer cell lines or normal fibroblast cells, followed by immunohistochemical study on tissue sections. Ninety-one monoclonal antibodies were obtained by above binding assays. One of them, named KM10 was further investigated. Isotype of KM10 was IgG1 with $\boldsymbol{\kappa}$-light chain. It was shown that KM10 has strong reactivity with tumors of colon, stomach, papilla Vater, and pancreas, while the limited reactivity displayed with normal tissues. The electron microscopic observation revealed that the antigen recognized by KM10 is expressed on the surface of cancer cells. KM10 could mediate ADCC. These results indicate that KM10 is a good candidate for a probe of diagnosis and therapy of cancer. —— monoclonal antibody ; gastrointestinal cancer
\end{abstract}

Monoclonal antibodies have provided a new powerful approach to diagnosis and therapy of cancer. Because monoclonal antibody is derived from an antibody producing cell clone, it is homogenous with respect to its subclass and specificity, and demonstrates specific binding to unique epitopes. Many monoclonal antibodies against malignant cells have been made (Edwin and Sikora 1982 ; Marx 1982 ; Damjanov and Knowles 1983; Abrams and Oldham 1985).

Received October 4, 1989; revision accepted for publication March 23, 1990.

Reprint requests: Y. Kano, Central Research Laboratories, the Green Gross Corporation, 2-1180-1 Shodai-ohtani, Hirakata 573, Osaka, Japan.

Abbrreviations used are: ELISA, enzyme-linked immunosorbent assay; PBS, phosphate-buffered saline; BSA, bovine serum ablumin ; CEA, carcinoembryonic antigen ; SRBC, sheep red blood cell ; PHA, passive hemagglutination assay ; RPHA, reverse passive hemagglutination assay; ADCC, antibody-depenent cell-mediated cytotoxicity. 
Some of them were used for the clinical trials in diagnosis and/or therapy (Nadler et al. 1980 ; Dillman et al. 1982 ; Sears et al. 1982 ; Oldham et al. 1984 ; Goodman et al. 1985 ; Houghton et al. 1985). In addition, trials with immunoconjugates, which monoclonal antibodies are coupled to some toxins or anti-cancer drugs, were also reported (Frankel et al. 1986 ; Spitler et al. 1987). In most studies, monoclonal antibodies or immunoconjugates were administered safely with less severe side reaction, but their clinical effects were not estimated yet. This paper reports on the establishment of hybridomas, and screening the hybridomas by binding assays and immunohistochemical assays. Approximately, 10,000 hybridomas were established as a result of 14 cell fusion experiments. We here describe the production and the characterization of monoclonal antibody KM10 which detects distinct antigenic determinants associated with human gastrointestinal cancer. This antibody is a good candidate for diagnosis and therapy of cancer for its biological activity and the antigen specificity.

\section{Materials and Methods}

Animals. Six to 12-week old male Balb/c mice were used for the immunization and for the production of monoclonal antibodies as ascitic fluid. Mice were purchased from Charles River Japan Inc., Tokyo.

Cell lines. Lung cancer cell lines (PC-1, PC-3, PC-9, PC-10), stomach cancer cell lines (MKN-28, MKN-45, KATO-III), renal cancer cell line (NRC-12) and bladder cancer cell line (NBT-2) were purchased from Immunologocal and Biological Laboratory, Takasaki. Esophagus cancer cell lines (TE-1, TE-2, TE-3, TE-5, TE-7, TE-9) were kindly provided by Dr. T. Nishihira (Tohoku University, Sendai). The cell line HEK was established in our laboratory from the specimens of the patient bearing bilary duct carcinoma. Other cell lines used in this study were purchased from Dainihon Pharmaceutical Company, Osaka. All cancer cell lines except for hybridomas were cultured in RPMI 1640 supplemented with $10 \%$ heat inactivated fetal calf serum (FCS).

Immunization and cell fusion. Mice were immunized intraperitonealy (i.p.) by three to four biweekly injection of $10^{7}$ cancer cells. The mouse showing the highest titer of antibody by ELISA was sacrificed 3 days after the last booster to prepare spleen cells for fusion. When the membrane protein was used instead of whole cells, mice were immunized subcutaneously (s.c.) with $0.1 \mathrm{mg}$ of protein emulsified in complete Freund's adjuvant. The last booster was i.p. injection without adjuvant. The cell fusion was performed according to the method of Galfre et al. (1977) with a slight modification. In brief, immunized spleen cells were fused with mouse myeloma cells P3-X63-Ag8 653 or P3-X63-Ag8-U1 at a ratio of $4: 1$ (splenocytes: myeloma) in the presence of $45 \%$ polyethylene glycol 4000 for $1 \mathrm{~min}$. Fused cells were resuspended at the concentration of 0.5 to $1.0 \times 10^{6}$ cells $/ \mathrm{ml}$ in DMEM medium containing $10 \%$ horse serum and seeded to 96 well tissue culture microplate at 100 $\mu \mathrm{l}$ /well. After overnight cultivation, $100 \mu \mathrm{l}$ /well of hypoxanthine-aminopterin-thymidine supplemented medium (HAT medium) was fed to each well and half of the medium was exchanged to HAT medium on every second day. After 10 to 14 days, culture supernatant was screened for the reactivity with cancer cells used as the immunogen and control cells, fibroblast Flow 2000. Desirable hybridomas were cloned by the limiting dilution method. The isotype of antibody was determined by Ouchterlony method. Ascitic fluid was produced by i.p. injection of $10^{7}$ hybridoma cells into pristane primed mouse. Monoclonal antibody was purified from the ascites by ammonium precipitation and high performance liquid chromatography on a TSK G3000SW column (Toso, Tokyo). 
Binding assays. Binding activity of antibodies to the immunogen was measured by ELISA. Membrane protein which was prepared as described before (Ohyanagi et al. 1987) was diluted in PBS and dispensed $50 \mu 1$ each into 96 well EIA plate. Kept overnight at $4^{\circ} \mathrm{C}$, the plate was washed 6 times with PBS and incubated overnight at $4^{\circ} \mathrm{C}$ with $200 \mu \mathrm{l} /$ well of PBS containing $1 \%$ BSA in order to reduce nonspecific binding. When whole cells were used, target cells were cultured overnight in 96 well microplate (Costar 3590) at the concentration of 0.5 to $1.0 \times 10^{5}$ cells $/$ well. Then, the plate was flicked, washed 3 times and $50 \mu \mathrm{l}$ of $0.1 \%$ glutaraldehyde was added to each well to fix the cells for $10 \mathrm{~min}$ at room temperature. After 3 times washing with PBS, $200 \mu \mathrm{l} /$ well of PBS containing $1 \%$ BSA was added as described above. After 6 times washing, $50 \mu \mathrm{l}$ monoclonal antibody was added and the plate was incubated at $37^{\circ} \mathrm{C}$ for $1 \mathrm{hr}$. Subsequently, after washing, $50 \mu \mathrm{l}$ of horseradish peroxidase conjugated rabbit anti-mouse immunoglobulin $(\operatorname{IgA}+\operatorname{IgM}+\operatorname{IgG})$ (Zymed Lab., Inc., San Francisco, CA, USA) was added, and the plate was incubated for 1 $\mathrm{hr}$ then was washed. Fifty microliters of $o$-phenylenediamine $(0.8 \mathrm{mg} / \mathrm{ml})$ containing $0.006 \% \mathrm{H}_{2} \mathrm{O}_{2}$ was added to the plate and the plate was incubated at room temperature for $30 \mathrm{~min}$. The peroxidase reaction was stopped by adding $50 \mu \mathrm{l}$ of $2 \mathrm{~N}-\mathrm{H}_{2} \mathrm{SO}_{4}$ and the absorbance at $492 \mathrm{~nm}$ was read on a Titertek Multiskan spectrophotometer (Flow Lab., Inc., McLean, CA, USA). Reactivity of monoclonal antibodies to CEA was determined by the following two procedures; One was ELISA. Rabbit anti-CEA (Dako, Santa Barbara, CA, USA) was diluted 500-fold with $0.05 \mathrm{M}$ bicarbonate buffer ( $\mathrm{pH} 9.6$ ). Fifty $\mu 1$ of diluted anti-CEA was added to each well of EIA plate and the plate was incubated overnight at $4^{\circ} \mathrm{C}$. After washing with PBS, $50 \mu \mathrm{l}$ of CEA (Dako, Santa Barbara, CA, USA) at the concentration of $400 \mathrm{ng} / \mathrm{ml}$ in PBS containing $1 \%$ BSA was added and incubated overnight at $4^{\circ} \mathrm{C}$. The plate was washed with PBS and then the remaining nonspecific binding sites were blocked by the addition of $200 \mu \mathrm{l}$ /well of PBS containing $1 \%$ BSA. The following procedure was the same as described above for membrane protein or cancer cell coating plate. The another method was based on the passive hemagglutination assay (PHA). According to the method of Uemura et al. (1986), CEA was coupled with SRBC(CEA-PHA). CEA-RPHA-CEA reagent was prepared by coupling CEA with SRBC via murine anti-CEA monoclonal antibody (BD6), which was previously coupled to SRBC. The PHA test was done in U-shaped microplate wells containing $25 \mu \mathrm{l}$ of antibody solution diluted two-fold and $25 \mu \mathrm{l}$ of $0.5 \%$ suspension of the PHA reagent. The diluent used in the test was a component of Hebsgencel ${ }^{\circledR}$ (The Green Cross Corp., Osaka) containing SRBC stroma and animal sera to prevent nonspecific reactions. The hemagglutination pattern was examined after $2 \mathrm{hr}$ of incubation at room temperature and the titer was expressed as the highest dilution of the sample showing hemagglutination.

Immunohistochemical assays. Normal and malignant human tissues were obtained at the surgery from the 1st Department of Surgery, Kobe University School of Medicine. Immediately upon removal from the patients, they were fixed with $4 \%$ paraformaldehyde in $0.1 \mathrm{M}$ phosphate buffer $(\mathrm{pH} 7.4)$ at $4^{\circ} \mathrm{C}$ overnight or quickly frozen in liquid nitrogen, after which they were stored at $-80^{\circ} \mathrm{C}$ until used. Paraformaldehyde-fixed tissues were used for the initial immunohistochemical screening of monoclonal antibodies selected by the binding assay. Five- $\mu \mathrm{m}$ thick sections of fixed tissues were air-dried, rinsed with PBS and incubated in methanol containing $0.3 \% \mathrm{H}_{2} \mathrm{O}_{2}$ for $20 \mathrm{~min}$ to block endogeneous peroxidase activity. After washing in PBS, the sections were dipped in PBS containing 3\% goat serum for $20 \mathrm{~min}$. Monoclonal antibodies were added to the sections and incubated for $1 \mathrm{hr}$ at room temperature. After removal of the antibody and washing with PBS, horseradish peroxidase conjugated goat anti-mouse IgG + IgM (Tago, Inc., Burlingame, CA, USA) was added and incubated further $1 \mathrm{hr}$. After a rinse with PBS, peroxidase reaction was initiated using $0.02 \%$ diaminobenzidine and $0.05 \% \mathrm{H}_{2} \mathrm{O}_{2}$ in $0.05 \mathrm{M}$ Tris- $\mathrm{HCl}$ buffer ( $\left.\mathrm{pH} 7.6\right)$. The sections were counterstained with $1 \%$ methylgreen in Veronal acetate buffer ( $\mathrm{pH} 4.0)$ before mounting. The selected antibodies through immunohistochemical assay using paraformaldehyde-fixed tissues were further investigated with fresh frozen sections, which 
were $5-\mu \mathrm{m}$ thick and air dried for several hours. Following the acetone treatment at $-20^{\circ} \mathrm{C}$ for $10 \mathrm{~min}$, they were dried quickly. After blocking the endogenous peroxidase activity by $\mathrm{H}_{2} \mathrm{O}_{2}$ and methanol, the sections were processed by the same method as described above for the paraformaldehyde-fixed tissue sections. The sections were scored according to the positive percentage of cells : that is, strongly positive; staining more than $50 \%$ of the cells in the specimen, moderately positive; staining more than $10 \%$ of the cells in the specimen, weakly positive; very slightly staining or negative.

Electron microscopical immunohistochemical assay. Five- $\mu \mathrm{m}$ thick sections of paraformaldehyde-fixed tissue were air-dried for $30 \mathrm{~min}$ and washed 3 times with cold PBS containing $10 \%$ sucrose. After 20 min incubation with PBS containing $3 \%$ normal goat serum at room temperature, monoclonal antibody was added and reacted overnight at $4^{\circ} \mathrm{C}$. Then, the sections were washed with cold PBS and $\mathrm{F}\left(\mathrm{ab}^{\prime}\right)_{2}$ of horseradish peroxidase labeled anti-mouse IgG (Tago, Inc., Berlingame, CA, USA) was added. The reaction was carried out for $6 \mathrm{hr}$. After washing with PBS containing 10\% sucrose, the sections were refixed with $1 \%$ glutaraldehyde for 5 min at $4^{\circ} \mathrm{C}$. After washing with PBS, they were soaked in $0.05 \mathrm{M}$ Tris- $\mathrm{HCl}$ buffer ( $\mathrm{pH} 7.6$ ) containing $0.02 \%$ diaminobenzidine and $1 \%$ dimethylsulfoxide for $30 \mathrm{~min}$. Then the peroxidase reaction was initiated in Tris-HCl buffer ( $\mathrm{pH} 7.6$ ) plus $0.05 \% \mathrm{H}_{2} \mathrm{O}_{2}$. After $5 \mathrm{~min}$ at room temperature, the sections were washed with PBS and fixed with $2 \%$ osmium tetraoxide for $1 \mathrm{hr}$ at room temperature. After dehydration in ethanol, the sections were embedded in epoxi resin. Ultrathin sections were stained with Reynold's lead staining solution and observed using transmission electron microscope (JEM-100S).

ADCC test. Spleen cells of normal 8-week old Balb/c mice were used as effector cells and human stomach cancer MKN-45 cells were used as target cells. MKN-45 cells were incubated for $4 \mathrm{hr}$ at $37^{\circ} \mathrm{C}$ at a concentration of $1 \times 10^{6}$ cells $/ \mathrm{ml}$ in RPMI-1640 medium containing $10 \% \mathrm{FCS}$ and $20 \mathrm{mM}$ of HEPES. This medium was used throughout the procedure. After washing with PBS, target cells were labeled with $\mathrm{Na}_{2}{ }^{51} \mathrm{CrO}_{4}$ (New England Nuclear, Boston, MA, USA) for $16 \mathrm{hr}$ with $50 \mu \mathrm{Ci}{ }^{51} \mathrm{Cr} / 10^{6}$ cells. Washed 3 times with above medium, then, they were cultured $2 \mathrm{hr}$ at $37^{\circ} \mathrm{C}$. Labeled target cells were washed and added to 96 well U-bottomed microplate at the concentration of $1 \times 10^{4}$ cells $/ 50$ $\mu \mathrm{l} /$ well. They were incubated for $2 \mathrm{hr}$ at $37^{\circ} \mathrm{C}$, and then, $50 \mu \mathrm{l}$ of monoclonal antibody were added. After further incubation for $1 \mathrm{hr}$, supernatant was sucked up and effector cells were added to each well. After overnight incubation, supernatant was collected and the release of radioactivity was measured. Percent of cytotoxicity was calculated with the following formula;

$$
\% \text { cytotoxicity }=\frac{\text { test } \text { or control release-spontaneous release }}{\text { maximal release-spontaneous release }} \times 100
$$

Maximal release was the total labeled level of $1 \times 10^{4}$ of target cells. Spontaneous release was determined by incubating target cells with effector cells without antibody.

\section{Results}

Development of hybridomas. Approximately 10,000 hybridomas were generated from 14 cell fusion experiments. Antibodies produced by these hybridomas were screened by the binding assay against the cancer cells used for the immunization and fibroblast Flow 2000. Hybridomas producing antibodies bound to immunogen but not to Flow 2000 were cloned. As a result of this initial screening, 91 monoclonal antibodies were selected which defined antigens expressed preferentially on cancer cells. These antibodies were tested by the imunohistochemical assay on paraformaldehyde-fixed sections from gastrointestinal car- 
cinomas and normal tissues corresponded with them. One monoclonal antibody tentatively named KM10 was selected based on the strength of the reaction to cancer tissues and on the restricted distribution of the antigen to normal tissues. KM10 was produced by the hybridoma established by using the spleen cells immunized with MKN-45. The isotype of it was IgG1 with $x$-light chain.

Reactivity of KM10 with cancer cell lines. The reactivity of KM10 to various cancer cell lines was tested. As shown in Fig. 1, KM10 strongly reacted with MKN-45 and KATO-III. The antibody also reacted with PC-3, HEK and several other cell lines, though the reactivity is far less than that shown in MKN-45 and KATO-III. Fig. 2a shows that KM10 reacts with CEA in ELISA system. But KM10 was not detected by CEA-PHA, whereas it was detected by CEA-RPHA-CEA (Table 1).

$A D C C$ activity of KM10. The ADCC activity of KM10 was measured by

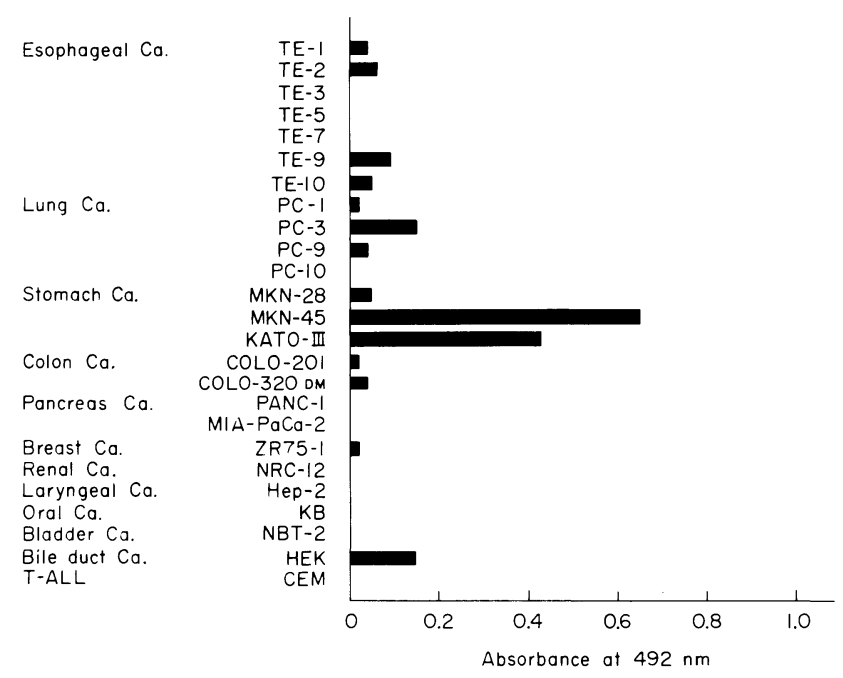

Fig. 1. Reactivity of KM10 with human cancer cell lines. The concentration of monoclonal antibody was $1 \mu \mathrm{g} / \mathrm{ml}$. For details of the procedure, see "Materials and Methods."

TABLE 1. Reactivity of KM10 with $C E A$

\begin{tabular}{ccc}
\hline $\begin{array}{c}\text { Antibody } \\
(5 \mu \mathrm{g} / \mathrm{ml})\end{array}$ & CEA-PHA & CEA-RPHA-CEA $^{\mathrm{a}}$ \\
\hline KM10 & ND & $1: 256$ \\
BD6 & $1: 51200$ & ND \\
\hline
\end{tabular}

ND, not detected.

${ }^{a}$ CEA-RPHA-CEA reagent was prepared by coupling CEA with SRBC via anti-CEA monoclonal antibody (BD6) previously coupled to SRBC. 
TABLE 2. ADCC activity of monoclonal antibodies

\begin{tabular}{rrrrrrr}
\hline & \multicolumn{3}{c}{ \% Cytotoxicity with antibody at 0.5 or $5 \mu \mathrm{g} / \mathrm{ml}$} \\
E/T ratio & \multicolumn{2}{c}{ KM10 } & \multicolumn{3}{c}{ BD6 } & \multicolumn{2}{c}{$1 \mathrm{D} 6$} \\
\cline { 2 - 7 } & 0.5 & 5 & 0.5 & 5 & 0.5 & 5 \\
\hline 1000 & 12 & 20 & 4 & 16 & 0 & 1 \\
300 & 23 & 20 & 7 & 8 & $\mathrm{NT}$ & $\mathrm{NT}$ \\
100 & 7 & 6 & 3 & 3 & 0 & 9 \\
30 & 0 & 6 & 2 & 3 & $\mathrm{NT}$ & $\mathrm{NT}$ \\
\hline
\end{tabular}

NT, not tested.

the ${ }^{51} \mathrm{Cr}$ release method using mouse splenocytes as effector cells. As shown in Table 2, KM10 showed as much as $23 \% \mathrm{ADCC}$ at $300 \mathrm{E} / \mathrm{T}$ ratio and $0.5 \mu \mathrm{g} / \mathrm{ml}$ of antibody. Non-specific monoclonal antibody such as anti-HBs monoclonal antibody, 1 D6 (Uemura et al. 1986), showed little activity. Other anti-CEA monoclonal antibody, BD6(IgG3), developed from the same series of experiment in which KM10 was obtained, showed some activity, although at far lower levels compared with KM10, in spite that the expression ratio of the antigen of this antibody on MKN-45 cells was greater than that of KM10 (Fig. 2b).
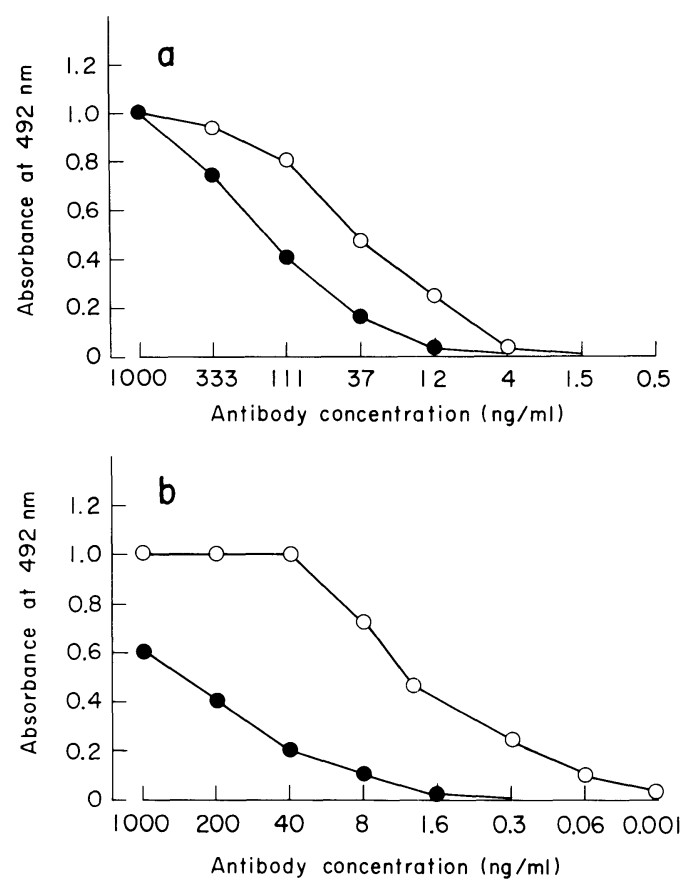

Fig. 2. Reactivity of KM10 and BD6 with CEA in the sandwich ELISA (a) and MKN-45 cells (b). - $\bullet$ KM10; $\bigcirc-$, BD6. For detalis of the procedure, see "Materials and Methods." 
TABLE 3. Immunohistochemical reaction of KM10 with paraformaldehyde-fixed sections

\begin{tabular}{|c|c|c|c|c|}
\hline Tissues & Negative & $\begin{array}{l}\text { Weakly } \\
\text { positive }\end{array}$ & $\begin{array}{l}\text { Moderately } \\
\text { positive }\end{array}$ & $\begin{array}{l}\text { Strongly } \\
\text { positive }\end{array}$ \\
\hline \multicolumn{5}{|l|}{ Malignant tumors } \\
\hline Colon & 0 & 1 & 1 & 8 \\
\hline Stomach & 5 & 4 & 4 & 18 \\
\hline Papilla Vater & 0 & 0 & 0 & 3 \\
\hline Pancreas & 2 & 1 & 3 & 1 \\
\hline Liver & 10 & 0 & 1 & 0 \\
\hline Esophagus & 1 & 1 & 1 & 0 \\
\hline Breast & 1 & 0 & 0 & 0 \\
\hline Thyroid gland & 1 & 0 & 0 & 0 \\
\hline Gallbladder & 2 & 0 & 0 & 0 \\
\hline \multicolumn{5}{|l|}{ Normal tissues } \\
\hline Colon & 4 & 10 & 2 & 0 \\
\hline Stomach & 21 & 10 & 3 & 0 \\
\hline Small intestine & 2 & 1 & 0 & 0 \\
\hline Esophagus & 0 & 3 & 1 & 0 \\
\hline Liver & 4 & 0 & 0 & 0 \\
\hline Pancreas & 7 & 0 & 0 & 0 \\
\hline Lung & 2 & 0 & 0 & 0 \\
\hline Kidney & 1 & 0 & 0 & 0 \\
\hline Mammary gland & 2 & 0 & 0 & 0 \\
\hline Thyroid gland & 1 & 0 & 0 & 0 \\
\hline Adrenal gland & 1 & 0 & 0 & 0 \\
\hline Gallbladder & 2 & 0 & 0 & 0 \\
\hline Lymph node & 3 & 0 & 0 & 0 \\
\hline
\end{tabular}

TABLE 4. Immunohistochemical reaction of KM10 with fresh frozen sections

\begin{tabular}{lcccc}
\hline \multicolumn{1}{c}{ Tissues } & Negative & $\begin{array}{c}\text { Weakly } \\
\text { positive }\end{array}$ & $\begin{array}{c}\text { Moderately } \\
\text { positive }\end{array}$ & $\begin{array}{c}\text { Strongly } \\
\text { positive }\end{array}$ \\
\hline Malignant tumors & 0 & 0 & 0 & 4 \\
Large intestine & 0 & 1 & 1 & 1 \\
Stomach & 0 & 0 & 2 & 0 \\
Pancreas & 0 & 1 & & \\
Normal tissues & 0 & 1 & 3 & 0 \\
$\quad$ Large intestine & 2 & 0 & 0 & 0 \\
Stomach & & & & \\
Pancreas & & &
\end{tabular}


Immunohistochemical reactivity of KM10. Monoclonal antibody KM10 was further investigated on the paraformaldehyde-fixed sections from variety of tissues and on frozen sections. Table 3 presented data from paraformaldehydefixed sections and Table 4 from frozen sections. There seemed no fundamental
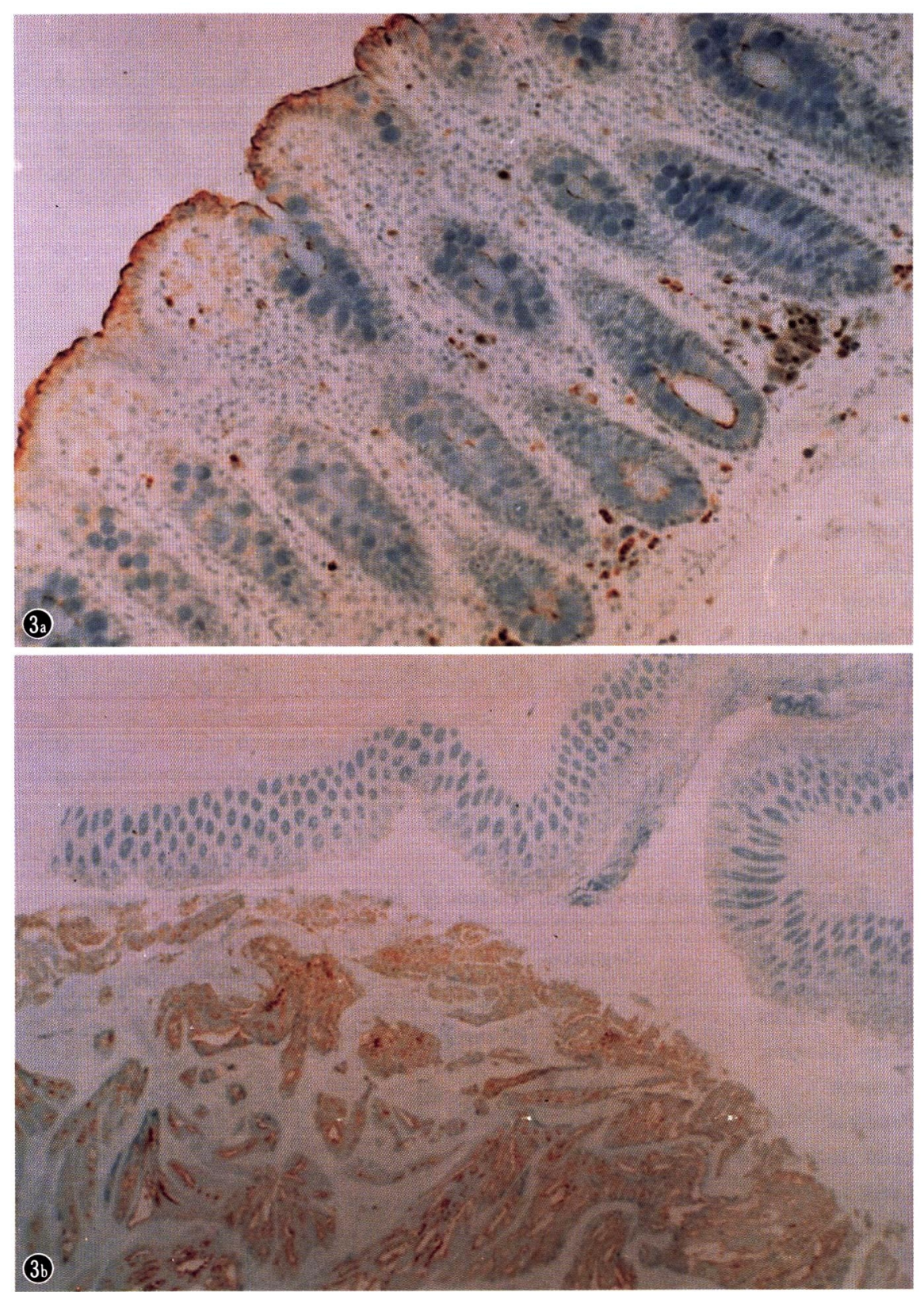

Fig. 3. Immunohistochemical reactivity of KM10 with normal (a) and malignant (b) colon tissue. 
difference between the results of these two experiments. KM10 reacted well with tumors of digestive organs such as colon, stomach, papilla Vater and pancreas. The ratios of positive staining with those paraformaldehyde-fixed sections were 10 out of $10(100 \%), 26$ out of $31(84 \%), 3$ out of $3(100 \%)$, and 5 out of $7(71 \%)$, respectively. Though KM10 reacted with normal mucosa of colon, stomach, small intestine and esophagus, the reaction was restricted to luminal surface of the columnar cells. Fig. $3 \mathrm{a}$ and $3 \mathrm{~b}$ shows the typical reaction of KM10 with normal and malignant colon tissues. The electron microscopic observation revealed that KM10 reacted with the cell membrane along the cell nest of the cancer cells,

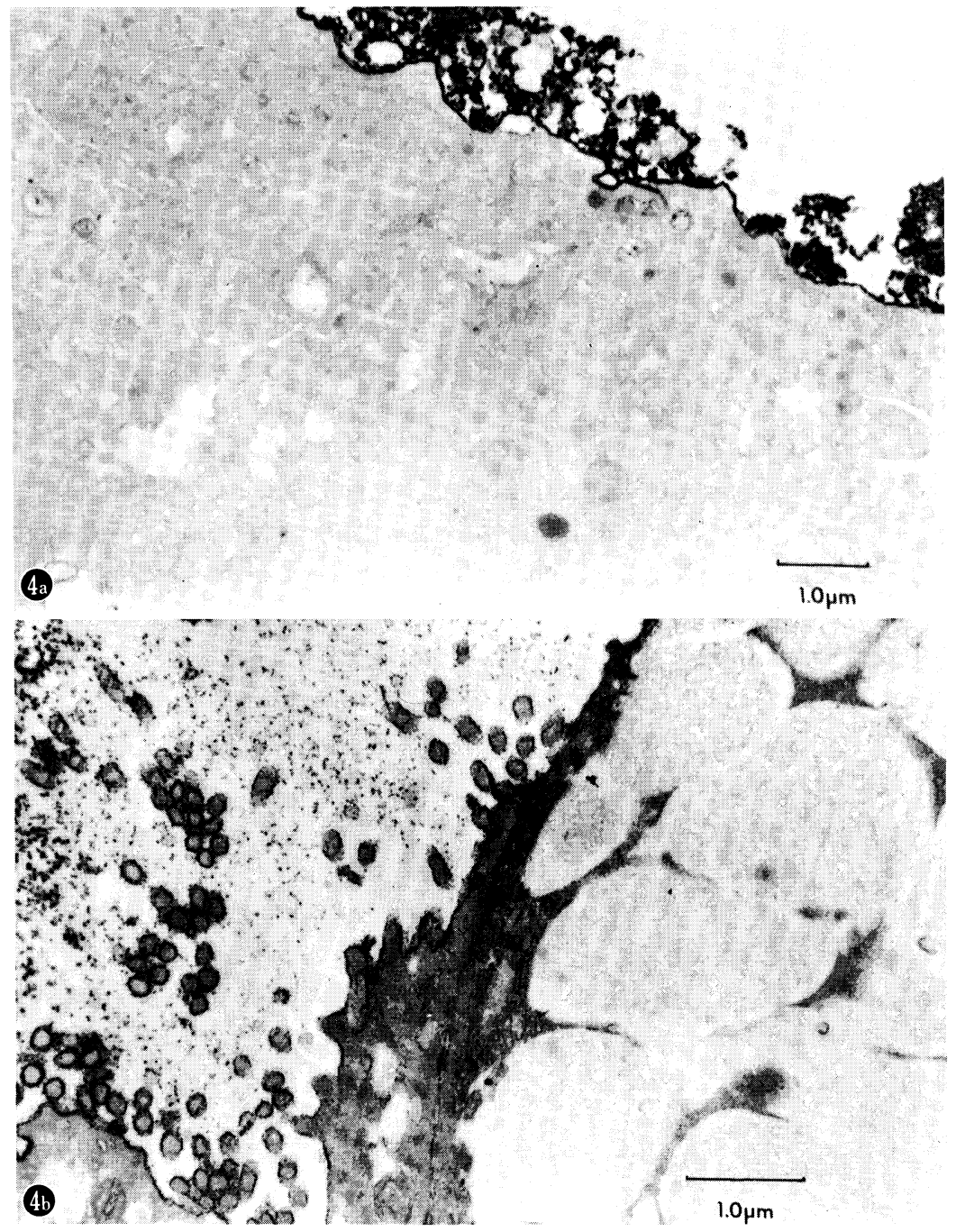

Fig. 4. Electron microscopical immunohistochemical reaction of KM10 with colon cancer (a) and normal colon (b). 
whereas it reacted weakly on the cell membrane at the site of cancer cell junction. In the normal colon, KM10 reacted on the luminal surface and microvilli of epithelial cell. The basal side of the epithelial cell did not show the reaction (Fig. 4).

\section{Discussion}

We have established approximately 10,000 hybridomas using spleen cells of mice immunized with human cancer cell lines and screened for the monoclonal antibodies by binding assays, followed by immunohistochemical staining on tissue sections. Ninety-one monoclonal antibodies were selected through the binding assay. The monoclonal antibody KM10, which further investigated after the initial immunohistochemical assays, reacts with KATO-III, PC-3, HEK, and several other cell lines besides MKN-45, the immunogen. These cell lines listed above are known to secret CEA (Uesaka et al. unpublished). KM10 binds to CEA in sandwich ELISA and the epitope seems to be a rather minor component in the CEA preparation, because KM10 did not react with CEA by CEA-PHA, which CEA molecules are randomly bound to SRBC. The distribution pattern of the antigen recognized by KM10 in human tissues coinsides with that of CEA reported by Ahnen et al. (1982). Kuroki et al. (1984, 1987) has reported the results of intensive analysis of the epitopes on CEA by using more than 100 monoclonal antibodies established by immunizing different CEA preparations and CEA-related antigens. They demonstrated that the antigenic structure of CEA can be divided into 5 antigenic parts at least and each part has some subgroups. Through the series of present cell fusion experiments, we have also established several hybridomas producing monoclonal antibodies which react with CEA. Soyama et al. (1989) suggested that KM10 recognized the distinctive part CEA by the mutual inhibition assay using these antibodies. Ohyanagi et al. (1988) showed that the molecular weight of the antigen recognized by KM10 was about $180 \mathrm{kDa}$ and this protein was also recognized by anti-CEA monoclonal antibody. Ishida et al. (1988) reported that the antigenic epitope of KM10 was resistant against neuraminidase treatment and sodium periodate treatment, while sensitive to pronase treatment. This suggested that the antigenic epitope of KM10 was not a carbohydrate but a peptide portion. These results strongly indicated that KM10 recognizes the specific epitope of CEA. Some investigators reported that monoclonal antibodies of IgG1 isotype could mediate ADCC (Koprowski et al. 1979 ; Greenberg and Lydyard 1979; Imai et al. 1982). Kipps et al. (1985) and Steplewski et al. (1985) demonstrated the importance of the immunoglobulin isotype in ADCC by using the isotype switch varients. They indicated that the IgG2a isotype is far effective than that of IgG2b and IgG1. The isotype of KM10 is IgG1 and has a ADCC activity using mouse spleen cells as effector. The activity is specific for the antigen and depends on the isotype of the antibody. Monoclonal antibody of IgG3, which recognizes a different epitopes on MKN-45 
cells, has a little activity compared with KM10. The low activity of IgG3 isotype in directing ADCC conflicts with the results independently obtained by Cheresh et al. (1985) and Hellstrom et al. (1985). They reported that anti-GD3 monoclonal antibody of IgG3 showed high ADCC activity. The differences in the ADCC assay such as higher antibody concentration, or different target antigens may permit IgG3 to direct strong ADCC. From the results of the electron microscopic observation, the antigen recognized by KM10 is highly expressed on the surface of cancer cells. Ohyanagi et al. (1988) reported the strong antitumor effect of KM10-adriamycin conjugate in tumor xenograft. They showed the dose-sependent antitumor activity of KM10-adriamycin conjugate, while this conjugate was less toxic than free adriamycin. These results strongly suggest the promissing possibility of KM10 as a probe for the targeting therapy of cancer.

\section{References}

1) Abrams, P.G. \& Oldham, R.T. (1985) Monoclonal antibody therapy of solid tumors. In: Monoclonal Antibody Therapy of Human Cancer, edited by K.A. Foon \& A.C. Morgan, Martinus Nijhoff Publishing, Boston, pp. 103-120.

2) Ahnen, D.J., Nakane, P.K. \& Brown, W.R. (1982) Ultrastructual localization of carcinoembryonic antigen in normal intestine and colon cancer. Cancer, 49, 20772090.

3) Cheresh, D.A., Honsik, C.J., Staffileno, L.K., Jung, G. \& Reisfeld, R.A. (1985) Disialoganglioside GD3 on human melanoma serves as a relevant target antigen for monoclonal antibody-mediated tumor cytolysis. Proc. Natl. Acad. Sci. USA, 82, $5155-5159$.

4) Damjanov, I. \& Knowles, B.B. (1983) Biology of disease: Monoclonal antibodies and tumor-associated antigens. Lab. Invest., 48, 510-525.

5) Dillman, R.O., Shauler, D.L. \& Sorbol, R.E. (1982) Murine monoclonal antibody therapy in two patients with chronic lymphocytic leukemia. Blood, 59, 1036-1041.

6) Edwin, S.L. \& Sikora, K. (1982) Diffinition of human tumor antigens. In : Monoclonal Antibodies in Clinical Medicine, edited by A.J. McMichael \& J.W. Fabre, Academic Press, London, pp. 111-128.

7) Frankel, A.E., Houston, L.L. \& Issel, B.F. (1986) Prospects for immunotoxin therapy in cancer. In: Ann. Rev. Med., edited by W.P. Creger, C.H. Coggins \& E.W. Hancock, Vol. 37. Annual Review Inc., Stanford, pp. 125-142.

8) Galfre, G., Howe, S.C., Milstein, C., Butcher, G.W. \& Howard, J.C. (1977) Antibodies to major histocompatibility antigens produced by hybrid cell lines. Nature, 266, 550-552.

9) Goodman, G.E., Beaumier, P., Hellstrom, I., Fernyhough, B. \& Hellstrom, K.E. (1985) Pilot trial of monoclonal antibodies in patients with advanced melanoma. J. Clin. Oncol., 3, 340-352.

10) Greenberg, A.H. \& Lydyard, P.M. (1979) Observation of IgG1 anti-DNP hybridoma-mediated ADCC and the failure of three IgM anti-DNP hybridomas to mediate ADCC. J. Immunol., 123, 861-869.

11) Hellstrom, I., Brankovan, V. \& Hellstrom, K.L. (1985) Strong anti-tumor activities of IgG3 antibodies to a human melanoma-associated ganglioside. Proc. Natl. Acad. Sci. USA, 82, 1499-1502.

12) Houghton, A.N., Minzer, D., Gordon-Cardo, C., Welt, S., Fliegel, B., Vadhan, S., Carswell, E., Melamed, M.R., Oettgen, H.F. \& Old, L.J. (1985) Mouse monoclonal IgG3 antibody detecting GD3 ganglioside : A phase I trial in patients with malignant 
melamona. Proc. Natl. Acad. Sci. USA, 82, 1242-1246.

13) Imai, K., Pellegrino, M.A., Wilson, B.S. \& Ferrone, S. (1982) Higher cytolytic efficiency of an IgG2a than of an IgG1 monoclonal antibody reacting with the same (or spatially close) determinant on a human high-molecular-weight melanoma-associated antigen. Cell. Immunol., 72, 239-247.

14) Ishida, H., Ohyanagi, H., Okumura, S. \& Saitoh, Y. (1988) A monoclonal antibody, KM10 reactive with human gastrointestinal cancer. J. Jpn. Surg. Soc., 89, 508-515. (in Japanese with English abstract)

15) Kipps, T.J., Parham, P., Punt, J. \& Herzenberg, L.A. (1985) Importance of immunoglobulin isotype in human antibody-dependent cell-mediated cytotoxicity detected by murine monoclonal antibodes. J. Exp. Med., 161, 1-17.

16) Koprowski, H., Steplewski, Z., Mitchell, K., Herlyn, M., Herlyn, D. \& Fuhrer, P. (1979) Colorectal carcinoma antigens detected by hybridoma antibodies. Somatic Cell Genet., 5, 959-972.

17) Kuroki, Ma., Kuroki, Mo., Koga, Y. \& Matsuoka, Y. (1984) Monoclonal antibodies to carcinoembryonic antigen: A systematic analysis of antibody specificities by using related normal antigens and evidence for allotypic determinants on carcinoembryonic antigen. J. Immunol., 133, 2090-2097.

18) Kuroki, M., Arakawa, F., Higuchi, H., Matsunaga, A., Okamoto, N., Takakura, K. \& Matsuoka, Y. (1987) Epitope mapping of the carcinoembryonic antigen by monoclonal antibodies and establishment of a new improved radioimmunoassay system. Gann, 78, 386-396.

19) Marx, J.L. (1982) Monoclonal antibodies in cancer. Science, 216, 283-285.

20) Nadler, L.M., Stashenko, P., Hardy, R., Kaplan, W.D., Button, L.N., Antman, K.H. \& Schlossman, S.F. (1980) Serotherapy of a patient with a monoclonal antibody directed against a human lymphoma-associated antigen. Cancer Res., 40, 3147-3152.

21) Ohyanagi, H., Saitoh, Y., Okumura, S., Ishida, T., Uesaka, K., Ishida, H., Yamamoto, M., Uemura, Y., Kano, Y. \& Suyama, T. (1987) A new monoclonal-antibody-defined tumor marker (KM01) for pancreatic carcinoma. Mt. Sinai J. Med., 54, 393-400.

22) Ohyanagi, H., Ishida, H., Ishida, T., Soyama, N., Yamamoto, M., Okumura, S., Kano, Y., Ueda, Y. \& Saitoh, Y. (1988) A monoclonal antibody, KM10 reactive with human gastrointestinal cancer and its application for immunotherapy. Gann, 79, 1349-1358.

23) Oldham, R.K., Foon, K.A., Morgan, C., Woodhouse, C.S., Schroff, R.W., Abrams, P.G., Fer, M., Schoenberger, C.S., Farrell, M., Kimball, E. \& Sherwin, S.A. (1984) Monoclonal antibody therapy of malignant melanoma: In vivo localization in cutaneous metastasis after intravenous administration. J. Clin. Oncol., 2, 1235-1244.

24) Sears, H.F., Atkinson, B., Mattis, J., Ernst, C., Herlyn, D., Steplewski, Z., Harvy, P. \& Koprowski, H. (1982) Phase-I clinical trial of monoclonal antibody in treatment of gastrointestinal tumors. Lancet, 1, 762-765.

25) Soyama, N., Yamamoto, M., Ohyanagi, H. \& Saitoh, Y. (1989) Comparative studies on monoclonal antibody KM10 and anti-CEA monoclonal antibodies. J. Jpn. Surg. Soc., 39, 1834-1839. (in Japanese with English abstract)

26) Spitler, L.E., Rio, M., Khentigan, A., Wedel, N.I., Brophy, N.A., Miller, L.L., Harkonen, W.S., Resendorf, L.L., Lee, H.M., Mischak, R.P., Kawahata, R.T., Stoudemire, J.B., Fradkin, L.B., Bautista, E.E. \& Scannon, P.J. (1987) Therapy of patients with malignant melanoma using a monoclonal antimelanoma antibody-ricin A chain immunotoxin. Cancer Res., 47, 1717-1723.

27) Steplewski, Z., Spira, G., Blaszczyk, M., Lubeck, M.D., Radbruch, A., Illges, H., Herlyn, D., Rajewsky, K. \& Scharff, M. (1985) Isolation and characterization of anti-monosialoganglioside monoclonal antibody 19-9 class-switch variants. Proc. Natl. Acad. Sci. USA, 82, 8653-8657.

28) Uemura, Y., Fukuyama, K., Nishida, M., Suyama, T. \& Ohori, H. (1986) Establish- 
ment of passive hemagglutination assay (PHA) system for anti-HBc in plasma. Tohoku J. Exp. Med., 149, 11-20. 